\title{
WIZERUNEK OSÓB Z NIEPELNOSPRAWNOŚCIAMI: STAN POSTULOWANY A RZECZYWISTY OBRAZ W MEDIACH ODTWORZONY NA PRZYKŁADZIE TYGODNIKÓW OPINIOTWÓRCZYCH
}

\section{Tomasz Wojakowski*}

\begin{abstract}
Abstrakt
Celem artykułu jest rekonstrukcja i porównanie odmiennych typów wizerunków osób niepełnosprawnych. Jeden to obraz postulowany w dyskursie publicznym elit symbolicznych. Drugi to obraz rzeczywisty naprawdę przedstawiany w przestrzeni medialnej. Po analizie tekstów artykułów opublikowanych wlatach 2017/2018 w trzech tygodnikach opiniotwórczych, zbadano i odtworzono rzeczywisty obraz osób z niepełnosprawnościami. Zestawienie obu wizerunków wykazuje istnienie rozdźwięku pomiędzy postulatami a stanem rzeczywistym, opartego na obrazie stygmatu, wykluczenia, zubożenia, uzależnienia od pomocy, niższej pozycji społecznej.
\end{abstract}

Słowa kluczowe: niepełnosprawność, wizerunek, media, stygmatyzacja, stereotypizacja, wykluczenie

\section{THE IMAGE OF PEOPLE WITH DISABILITIES:}

THE POSTULATED STATE AND THE REAL IMAGE IN THE MEDIA RECREATED ON THE EXAMPLE OF OPINION-FORMING WEEKLIES

Abstract

The main objective of this article is to reconstruct and compare images of different types of people with disabilities. One of them is an image postulated in the public discourse of symbolic elites. The second is a real image, i.e. one that is really presented in the media space. As a result of qualitative research involving the analysis of the texts of articles published during the period of one year (years 2017/2018) of three opinionforming weekly, has been explored and recreated the real image of people with disabilities. Comparing the two images have shown that there is a discrepancy between the postulates and the real state, which is based on the image of a stigma, exclusion and impoverishment, aid dependency, lower social position.

Keywords: disability, image, media, stigma, stereotyping, exclusion

\footnotetext{
*Mgr inż. Tomasz Wojakowski, autor niezależny, e-mail: twojakowski@gmail.com | ORCID: https://orcid.org/0000-0002-0507-5533
} 
Wprowadzenie

Osoby z niepełnosprawnościami, jako bardzo liczna grupa Polaków¹, znajdują się w głównym nurcie zainteresowania społecznego, w polityce kolejnych obozów rządzących czy aktywnej działalności organizacji pozarządowych. Równość tej grupy osób, w kontekście praw człowieka, wydaje się być niepodważalna. Powstają kolejne programy antydyskryminacyjne, systemy wyrównywania szans oraz inkluzji społecznej.

Konwencja ONZ o prawach osób niepełnosprawnych już wósmym na pięćdziesiąt artykułów wskazuje na znaczenie wizerunku osób z niepełnosprawnością i nakazuje Państwom-Stronom dokumentu podjęcie natychmiastowych działań, których celem jest podniesienie świadomości społeczeństwa w sprawach dotyczących osób niepełnosprawnych, a także prowadzenie kampanii na rzecz wzmocnienia poszanowania prawi godności tej grupy osób. Ważnym zapisem Konwencji jest oczekiwanie zwalczania stereotypów, uprzedzeń i szkodliwych praktyk wobec osób niepełnosprawnych wkażdej dziedzinie życia czy promowania wiedzy o ich zdolnościach i wkładzie ich pracy na rzecz różnych społeczeństw (Zgromadzenie Ogólne Narodów Zjednoczonych 2006).

Wychodząc naprzeciw wyzwaniom, jakie zawarto w przywołanym dokumencie, zasadniczym celem podjętego przez autora procesu badawczego uczyniono zaprezentowanie różnic pomiędzy społecznie postulowanym wizerunkiem osób z niepełnosprawnościami, a ich rzeczywistym obrazem wytwarzanym w przestrzeni medialnej. Rekonstrukcja

\footnotetext{
${ }^{1}$ W roku 2011 liczba osób niepełnosprawnych ogółem wynosiła niemal 4,7 mln, co stanowiło 12,2\% ludności kraju, wobec 14,3\% w roku 2002 (blisko 5,5 mln). Prawne potwierdzenie faktu niepełnosprawności posiadało w roku 2011 przeszło 3,1 mln osób (Biuro Pełnomocnika ds. Osób Niepetnosprawnych 2011). Według wyników Europejskiego Ankietowego Badania Zdrowia w roku 2014 w Polsce było 7,7 mln. osób niepełnosprawnych biologicznie, tj. osób, które zadeklarowały ograniczoną zdolność wykonywania czynności jakie ludzie zwykle wykonują (zgodnie z jednolitą dla UE definicją zastosowaną w badaniu uwzględniono zarówno poważne jak i mniej poważne ograniczenia, powodujące niemożność wykonywania ww. czynności, przez okres co najmniej ostatnich 6 miesięcy). Zatem w zależności od przyjętego kryterium poziomu ograniczeń, populacja osób niepełnosprawnych w Polsce może liczyć od 4,7 mln osób do 7,7 mln osób (Biuro Pełnomocnika Rządu ds. Osób Niepełnosprawnych 2015).
} 
tych dwóch wizerunków doprowadziła do odpowiedzi na pytanie o zakres i kształt tych różnic. Dodatkowe pytania, na które znaleziono odpowiedź, dotyczyły źródel tych różnic oraz kwestii związanych z tym, kto przyczynia się do kształtowania wizerunków osób z niepełnosprawnościami.

Odpowiedzi na tak sformułowane problemy badawcze poszukiwano poprzez analizę artykułów w opiniotwórczych tygodnikach: „Wprost”, „Newsweek” i „Polityka”. W budowaniu wizerunku dużą rolę odgrywają organizacje pozarządowe prowadzące działalność na rzecz osób niepełnosprawnych w Polsce. Analizie poddano także przykłady ich akcji oraz kampanii społecznych. W próbie odpowiedzi na pytania badawcze wzięto także pod uwagę publiczne postawy, wypowiedzi lub opinie osób stojących na czele wybranych organizacji trzeciego sektora. Są to często osoby niepełnosprawne, które będąc liderami tych środowisk, przyczyniają się swoją postawą i działalnością do kształtowania obrazu osób niepełnosprawnych.

Wielowymiarowe ujęcie niepełnosprawności

Właściwe określenie definicji niepełnosprawności jest ważne nie tylko dlatego, że pozwoli na uporządkowane omówienie tego zjawiska. Istotne jest także dlatego, że dookreślenie terminu odgrywa istotną rolę w procesie kształtowania wizerunku osób z niepełnosprawnościami. Dzięki temu definiuje się sytuację i kontekst tej kategorii społecznej. J eden stygmatyzujący zwrot lub obciążające słowo może obarczyć człowieka niechcianym wizerunkiem na całe życie (Krause 2009).

Zdefiniowanie pojęcia niepelnosprawności nie jest proste ze względu na różnorodność znaczeń w literaturze przedmiotu (Podgórska-J achnik 2013). Geof Mercer i Colin Barnes (2008) zauważają, że przez niemal cały XX wiek domonowało rozumienie niepełnosprawności jako „wady” ciała lub umysłu. Dysfunkcje powodują stan zależności od drugiego człowieka i jego pomocy. Zatem w takim wymiarze niepełnosprawność 
sprowadza się do „tragedii osobistej” i ciężaru dla społeczeństwa (Ibidem, s. 6). J ednak najczęściej mówiąc o niepełnosprawności, buduje się obraz opozycji do pojęcia zdrowia, które kwalifikowane jest jako stan normalny ${ }^{2}$.

W proces określenia pojęcia niepełnosprawności zaangażowani są przedstawiciele różnych dyscyplin naukowych. Swój wkład ma medycyna, socjologia, ale także psychologia, pedagogika czy nauki prawnicze. Podkreśla się, że wypracowanie jednej definicji jest potrzebne dla sformułowania rozwiązań systemowych służących poprawie jakości życia tej licznej społeczności (J anocha 2009).

W polskim prawodawstwie termin „osoba niepełnosprawna” po raz pierwszy pojawił się w uchwale Sejmu z 16 września 1982 roku w sprawie inwalidów i osób niepelnosprawnych (Nadolna, Piocha 2009). W tym akcie prawnym termin został tylko zasygnalizowany, natomiast definicja niepełnosprawności pojawia się w ustawie z 9 maja 1991 roku o zatrudnieniu i rehabilitacji zawodowej osób niepelnosprawnych (Ustawa 1991). Określa ona, że osoba niepełnosprawna to osoba o nieistotnym ubytku zdolności fizycznych, psychicznych lub umysłowych, ograniczającym zdolność do wykonywania pracy zarobkowej. Ta definicja odsunęła z polskiego prawodawstwa pojęcie inwalida.

Postępem w budowaniu pojęcia niepełnosprawności była Karta Praw Osób Niepełnosprawnych z roku 1997. Zawarte w niej sformułowania określały osoby niepełnosprawne jako osoby, których sprawność fizyczna, psychiczna lub umysłowa trwale lub okresowo utrudnia, ogranicza czy uniemożliwia życie codzienne, naukę, pracę oraz pełnienie ról społecznych zgodnie z normami prawnymi i zwyczajowymi. Mają one prawo niezależnego, samodzielnego i aktywnego życia oraz nie mogą

\footnotetext{
2 Przyjmując taką perspektywę, dewiacją społeczną była nazywana niepełnosprawność w socjologicznym ujęciu funkcjonalistycznego podejścia do choroby Talcotta Parsonsa (Mercer, Barnes 2008). Takie ukazanie osób chorych, w tym osób niepełnosprawnych, zakładało ich zagrożenie dla wydajności ekonomicznej społeczeństwa.
} 
podlegać dyskryminacji (Monitor Polski 1997). W kryteriach niepełnosprawności uwzględniono oprócz fizjologicznych, anatomicznych czy psychicznych, również te środowiskowo-społeczne.

W procesie definiowania zjawiska uczestniczy również Światowa Organizacja Zdrowia (WHO), która za osobę niepełnosprawną uznaje taką, która nie może samodzielnie, częściowo lub całkowicie, zapewnić sobie możliwości normalnego życia indywidualnego i społecznego na skutek wrodzonego lub nabytego upośledzenia sprawności fizycznej lub psychicznej (Szafraniec, Szymborski 2015). W tej definicji widocznejest odejście od określania przyczyn niepełnosprawności. Uwaga jest natomiast skupiona na skutkach, jakie powoduje niepelnosprawność w różnych dziedzinach życia.

W oparciu o taką definicję w 1980 roku została przyjęta przez WHO Międzynarodowa Klasyfikacja Uszkodzeń, Niepełnosprawności i Upośledzeń. Dokument ten został jednak skrytykowany, jako medykalizujący problemy osób z niepełnosprawnościami. Zaproponowana w nim klasyfikacja w sposób niewystarczający uwzględniała aspekt społeczny zjawiska niepełnosprawności, które zależy nie tyko od indywidualnych cech konkretnej osoby, ale również od tego jakie wymagania wytwarza otoczenie (Gustavsson, Zakrzewska-Manterys 1997).

W odpowiedzi na ten zarzut w 2001 roku WHO przedstawiło ostateczną wersję dokumentu - Międzynarodowej Klasyfikacji Funkcjonowania, Niepelnosprawności i Zdrowia - ICF. W zmodyfikowanej klasyfikacji termin niepełnosprawność zastąpiło „ograniczenie aktywności”, zaś „upośledzenie” - „ograniczenie uczestnictwa”. W związku z tym biopsychospołeczna koncepcja niepełnosprawności połączyła w sobie aspekt biologiczny oraz społeczny. W takim podejściu zwrócono uwagę, że bezpośrednią przyczyną zaburzeń funkcjonowania człowieka może być środowisko społeczne. Tak może się stać nawet przy braku uszkodzenia ciała, na przykład w stygmatyzacji osób wyleczonych z choroby psychicznej (Kilian 2007). 
Obecnie obserwowana jest zmiana w podejściu do niepelnosprawności, zarówno wnaukach społecznych i humanistycznych, jaki na gruncie polityki publicznej. Ewolucja polega na postrzeganiu osoby z niepelnosprawnością już nie jako jednostki obarczonej dysfunkcjami ciała, ale również osadzonej w społeczeństwie w kontekście zależności wzajemnych. Takie ujęcie implikuje oddziaływaniejednostki na otoczenie, przy jednoczesnym oddziaływaniu na nią otoczenia, w jakim się znajduje. Przyjęcie perspektywy społecznej w podejściu do problematyki niepełnosprawności daje nowe możliwości zorientowania się na działaniach integracyjnych oraz włączeniu społecznym. Nadaje to także właściwy sens oraz miejsce wciąż ważnej roli w procesie zdrowienia, zabiegów leczniczych czy działań rehabilitacji stricte medycznej (Niedbalski, Racław, Żuchowska-Skiba 2017).

Mateusz Wiliński (2010) podsumowującistniejące sposoby rozumienia i badania niepelnosprawności wyróżnia jej trzy modele: medyczny, społeczny oraz funkcjonalny (który łączy niejako kwestie czysto fizyczne ze społecznymi).

Model medyczny jest określany inaczej jako jednostkowy. Indywidualny charakter tego podejścia odnosi się do roli pacjenta, który jest zawsze konkretną osobą, dlatego nie ma tutaj szerszego spojrzenia na osobę oraz otoczenie, które na nią oddziałuje. Niepełnosprawność jest zatem problemem wyłącznie danej osoby (Karaś 2012).

Tezy zawarte w manifeście Związku Upośledzonych Fizycznie Przeciw Segregacji pod tytułem Fundamental Principles of Disability (Union of the Physically Impaired Against Segregation 1976) były wyjściem poza tą ciasną perspektywę. Tym sposobem został wprowadzony model społeczny. Zauważa się wnim, że niepełnosprawność powstaje w zetknięciu ze społeczeństwem i jego barierami. Swoistą barierą może być także sposób kreowania wizerunku osób z niepełnosprawnościami.

Trzeci model - funkcjonalny - opisuje niepełnosprawność jako zaczynającą się od fizycznego uszkodzenia ciała, które przekłada się na ograniczenia społeczne właśnie funkcjonalne. Oznacza zatem bariery 
w wykonywaniu określonych „funkcji” przez jednostkę (Karaś 2012). Perspektywa ta nie skupia się na uszkodzeniach ciała, ale na skutkach, jakie one powodują. Do tego modelu odwoływała się również definicja niepełnosprawności opracowana przez WHO w roku 2001 (World Health Organization 2001).

Wizerunek osób z niepełnosprawnościami w społeczeństwie

Pojęcie wizerunku (ang. image) wprowadził amerykański pisarz Walter Lippmann³ w roku 1922 (Tabernacka, Szadok-Bratuń 2012). Słownik języka angielskiego podaje natomiast, iż image to po pierwsze a mental picture or idea of sb/sth, czyli obraz lub wyobrażenie o kimś lub czymś; a po drugie a general impression that a person or an organization gives to the public, czyli ogólne wrażenie, jakie osoba lub organizacja robi na opinii publicznej (Stownik Oxford Wordpower 2002, s. 388). Walter Lippmann nadmienił, że z pewnością pojawią się rozbieżności pomiędzy światem zewnętrznym a jego obrazem, wizerunkiem wykreowanym w naszej wyobraźni (Baran, Davis 2007).

Aleksander Hulek (1991) opisując stosunek społeczeństw wobec osób niepełnosprawnych na przestrzeni wielu epok wymienił kilka sposobów traktowania osób niepełnosprawnych. Wskazał na odtrącanie ludzi niepełnosprawnych poza obręb społeczeństwa przez ludy pierwotne czy w starożytności, leczenie osób niepelnosprawnych, zamykanie ich w zakładach specjalnych czy wreszcie edukację segregacyjną. Do tego chronologicznego spisu można dodać integrację i inkluzję społeczną. I choć z tego wynika, że podejście do zjawiska niepełnosprawności jest coraz bardziej nacechowane humanizmem, to nie stanowi to przeszkody do tego, aby nastawienie społeczne pozostało jednocześnie negatywne. Jadwiga Kuczyńska-Kwapisz (2008) wskazuje na stale

3 Doradca niepełnosprawnego, poruszającego się na wózku inwalidzkim, amerykańskiego prezydenta Franklin Delano Roosevelta. 
obecne zakorzenione poglądy o społecznej nieprzydatności osób niepełnosprawnych pomimo ich rzeczywistych sukcesów.

Na podstawielektury artykułu Piotra Stanisławskiego (2003) można wyciągnąć wniosek, że ambiwalentne podejście do osób z niepełnosprawnościami jest obecne we współczesnych mediach. Oparta na myśleniu stereotypowym niechęć wobec osób z niepełnosprawnością ma swoje źródło między innymi w przesądach, a także wierzeniach, które biorą swój początek jeszcze w zamierzchłych czasach. Aby lepiej zrozumieć to zjawisko, wartojest w sposób bardziej szczegółowy przyjrzeć się praktykom, jakie obowiązywały w różnych kulturach na przestrzeni czasu.

Historia społecznej identyfikacji osób niepełnosprawnych zaczyna się od czasów starożytnej Grecji. We wszystkich przejawach życia obecny był tam silny kult ciała, jego idealnych proporcji, pełnej sprawności fizycznej. W świecie, w którym prawa pochodziły ze strefy nadprzyrodzonej będącej źródłem idealizmu, nie było miejsca dla ludzi kalekich. To dawało przyzwolenie dla eksterminacji istot zdeformowanych (Żuraw 2016). Drugą rolą dla osób niepełnosprawnych było zabawianie, dostarczanie rozrywki sprawnej części społeczeństwa. W starożytnej Grecji i Rzymie „dom, w którym nie było paru karłów, niemot, głupków, eunuchów czy garbusów, których głównym zadaniem zdawało się być uleganie poniżeniom i bolesnym upokorzeniom, by zapewnić rozrywkę w czasie obiadów czy innych uczt, był postrzegany jako nienadążający za modą" (Mercer, Barnes, 2008, s. 109).

O gorszej pozycji osób niepełnosprawnych, w odniesieniu do reszty społeczeństwa, mówią także biblijne zapisy Starego Testamentu - „żaden człowiek, który ma skazę, nie może się zbliżać - ani niewidomy, ani chromy, ani mający zniekształconą twarz ani kaleka (...) do ołtarza, bo ma skazę" (Biblia Tysiąclecia Nowego i Starego Testamentu 2000, s. 147). Dosłowne odczytywanie treści Pisma Świętego powodowało, że wkolejnych wiekach w kulturze ludowej panowało przekonanie, że niepełnosprawność jest efektem grzechu, zatem jest stanem zła. W tym właśnie 
okresie, w średniowieczu bardzo często miejscem pracy i życia dla tych osób bywał cyrk lub domy bogatych ludzi. Drugim miejscem była ulica ze znowu uwłaczającą rolą żebraka. Dla lepszego efektu dysfunkcje, deformacje były eksponowane, aby wzbudzić litość, a tym samym potencjalnie większą hojność (Korniszowski 2003).

Epoka średniowiecza wraz ze swoją negacją ciała, przyniosła zmiany w stosunku do niepelnosprawności. Oficjalne stanowisko św. Augustyna mówiło, że człowiek z dysfunkcją jest dziełem bożym, a nieoficjalnie zaprzeczano człowieczeństwu tych ludzi (Żuraw 2016). Powszechnym stanowiskiem było również postrzeganie dysfunkcji jako kary za grzechy przodków. Z tego powodu, jako praktykę ekspiacyjną, która miała niejako zadośćuczynić przewinieniom przeszłości, osoby niepełnosprawne były uśmiercane. Osoby niepełnosprawne były traktowane jako zagrożenie dla społeczeństwa. Niepełnosprawność była traktowana jako coś, co było trudno wyjaśnić. Wokół tego zjawiska wytwarzało się wrażenie osobliwości, zaś osoby niepełnosprawne były podejrzewane o niezwykłe umiejętności.

W XVII wieku państwo zaczęło się angażować w rozwiązywanie problemówludzi niepelnosprawnych. W roku 1601powstało wAnglii Prawo ubogich. Tak pojawiło się rozróżnienie na tych, którzy swoje złe położenie zawdzięczają samym sobie oraz tych, których status materialny jest wynikiem między innymi niepełnosprawności i im należy się pomoc (Żuraw 2016). W kolejnych stuleciach grupy osób poddawanych „opiece” były zamykane w specjalnych ośrodkach odosobnienia. J eszcze w XVII i XVIII wieku miały miejsce publiczne pokazy osób umieszczonych w domach wariatów" i zakładach psychiatrycznych (Mercer, Barnes 2008).

Kapitalizm dostarcza kolejnych zmian w sytuacji osób niepełnosprawnych. Ze względu na uznanie człowieka za siłę produkcyjną, kalectwo staje się tragedią osobistą. Dokonuje się unowocześnienie pracy, industrializacja, coraz częściej używa się maszyn, powstaje olbrzymi nacisk na szybkość, co wymusza dyscyplinę pracowników i przyczynia się 
do usuwania niepełnosprawnych z głównego nurtu pracy. W procesie produkcyjnym nastawionym na zysk dysfunkcyjne ciało było mało wydajne (Żuraw 2016). Osoby niepełnosprawne z wadami wrodzonymi były traktowane przez ówczesnych ewolucjonistów jako reprezentanci wcześniejszych stadiów rozwoju ludzkości (Stratford 1993).

W społeczeństwach wczesnonowożytnych ludzie poszukiwali pomocy u różnego rodzaju znachorów, medyków tamtych czasów. Natomiast XIX wiek staje się okresem, w którym następuje budowanie pozycji medycyny profesjonalnej. W ten sposób pojawia się nowe kryterium, które wprowadza medyczną dominację nad osobami niepełnosprawnymi, ujmując niepełnosprawność jako aspekt problemu psychosomatycznego jednostki i jej chorego ciała. Tym sposobem dokonała się instytucjonalizacja choroby i samej niepelnosprawności. Państwo zawłaszczyło sobie prawo do leczenia oraz szkolenia fachowców jednocześnie legitymizując ich autorytet.

J ednocześnie praktyki „pokazów osobliwości” kwitły jeszcze w XIX i na początku XX wieku w Europie i Ameryce Północnej. W Stanach Zjednoczonych obowiązywało „Prawo o brzydocie”. Nakładało ono społeczne ograniczenia na osoby, których wygląd był odrażający lub mógł być źródłem strachu dla „normalnych” ludzi. Zabraniało ono publicznego pokazywania się osób, które były „chore, okaleczone lub w inny sposób zdeformowane w taki sposób, że mogły stanowić mało przyjemny czy odrażający widok" (Mercer, Barnes 2008, s. 109).

Powyższe rozważania wskazują, że nie ma znaczenia przedział czasowy, dominująca ideologia czy aktualnie identyfikowane podejście. Osoby niepełnosprawne zawsze były traktowane jako inne, pochodzące spoza kręgu „normalności”, z którymi społeczeństwa próbują sobie na różne sposoby „poradzić” (np. zabijając, izolując, oswajając bądź medycznie klasyfikując). Osoba niepelnosprawna wzbudza specyficzne reakcjejest wskazywana, klasyfikowana, opisywana, następnie segregowana.

Terminami skorelowanymi z opisem zjawiska niepelnosprawności oraz z postrzeganiem osób z niepełnosprawnościami w społeczeństwie 
są również pojęcia: stereotypizacja, stygmatyzacja, dyskryminacja oraz wykluczenie społeczne. W literaturze socjologicznej istnieje wiele prac poświęconych tym pojęciom.

J ednostka poznając świat wykorzystuje własną percepcję, w wyniku czego w jej świadomości powstaje subiektywny obraz otoczenia. Na postrzeganą rzeczywistość wpływa aktualny stan emocjonalny i poprzednie doświadczenia. Spostrzeganie rzeczywistości jest stale przetwarzane. Otrzymane informacje i wrażenia są selekcjonowane i interpretowane zgodnie z posiadanymi danymi o otoczeniu. Tak powstają schematy poznawcze. W ich wyniku formułowane są sądy i decyzje na temat rzeczywistości społecznej (Aronson, Wilson, Akert 1997). J est to bardzo efektywny sposób poznawania świata, ponieważ dzięki uproszczeniom możliwe jest znaczne ograniczenie czasu potrzebnego na przeanalizowanie wszystkich docierających do jednostki informacji oraz innych bodźców. J ednak istnieje również ryzyko: łatwo może dojść do zafałszowania prawdziwego obrazu. Tak powstają błędne opinie na temat innych ludzi, następuje ich kategoryzowanie oraz rodzą się stereotypy.

Stereotypizacja przyjmuje formę uogólnionego wnioskowania polegającego na posługiwaniu się cechami całej zbiorowości w opisywaniu jednostki. Pozostawanie w takim schemacie uznawane jest za nierozsądne, pozbawione racjonalnego podejścia do osób czy społeczeństw obarczonych piętnem. Bywa też uznawane za moralnie negatywne (Nelson 2003). Negatywny stereotyp zjawiska niepełnosprawności pojawia sięjuż u osób stosunkowo młodych. Początkowojest to proces nieuświadomiony, a w efekcie internalizacji tego negatywnego obrazu dochodzi do celowego unikania kontaktu z osobami niepelnosprawnymi. Stają się one niejako przedstawicielami stereotypizowanej grupy (Ibidem). Zatem proces ten dotyczy społeczności, z którą jednostka może wcale nie mieć bezpośrednich kontaktów. 
Ciekawe zjawisko uwidacznia się również w postawach wobec osób niepełnosprawnych, które przejmowane są w wyniku dziedziczenia społecznego. Dostrzegane są rozbieżności pomiędzy zadeklarowanymi postawami, a rzeczywistymi zachowaniami otoczenia. To, co odbywa się w płaszczyźnie przekazu werbalnego, oparte jest na normach społecznych sugerujących opiekę, pomoc osobom chorym czy potrzebującym. Taka postawa wynika również z obawy przed negatywną oceną otoczenia. Ukrywa ono natomiast postawy wrogie, które niejednokrotnie nacechowane są antagonizmami (Sękowski 1994).

Postawy wobec osób niepelnosprawnych nabierają szczególnego znaczenia w aktualnie popularnym w mediach trendzie, który kładzie nacisk na wartości takiejak: zdrowie, atrakcyjność fizyczną, zamożność, produktywność. Z tych wyznaczników sukcesu może narodzić się nieprzychylny stosunek do niepełnosprawności (Ostrowska 1997).

Osoby z różnymi dysfunkcjami postrzegane są jako ułomne i oznaczone piętnem. J est to odrębna, inna część społeczeństwa, która może być traktowana właśnie inaczej. Cielesność dla osób z niepełnosprawnościami jest obszarem opresji, zarówno z powodu wyglądu ciała, jak i stosunku do nich samych. Nadal, bezjakichkolwiek zmian w myśleniu potocznym oraz polityce publicznej, w związku z uwarunkowaniami biologicznymi czy ułomnościami umysłu, dochodzi do zjawiska wykluczenia osób niepełnosprawnych (Mercer, Barnes 2008).

Terminem, który obrazuje sposób tworzenia się uprzedzeń oraz ukazuje, jak negatywnie naznaczenia wpływają na funkcjonowanie osoby niepelnosprawnej, jest stygmatyzacja lub nadawanie piętna. Pojęcia te powestały w starożytnej Grecji i były używane jako „określenie znaków cielesnych sygnalizujących, że ze statusem moralnym ich nosiciela wiąże się coś nadzwyczajnego i złego zarazem" (Goffman 2007, s. 31).

Erving Goffman podał definicję piętna w odniesieniu do zjawisk socjologicznych. „Terminu «piętno» będziemy zatem używać na określenie atrybutu dotkliwie dyskredytującego" (Ibidem, s. 33). Przywołane 
wcześniej jako relikt przeszłości biblijne przekonanie społeczne, że niepełnosprawność jest efektem grzechu, u Goffmana nadal jest postrzeganejako kara. Skarcenie od losu jest przyczyną tego, co dana osoba, jej rodzice lub grupa, do której przynależy, zrobili kiedyś w swoim życiu. Taki pogląd jeszcze bardziej stygmatyzuje osobę niepełnosprawną, w wyniku czego bardzo prawdopodobne jest to, że poszukuje ona winy w sobie lub w najbliższym otoczeniu. Erving Goffman odnosząc się do pojęcia piętna i wykluczenia zauważa, że nie tylko osoby, które posiadają jakiś stygmat, ale też osoby „normalne” w trakcie całego życia nie spełniają jakiś norm społecznych. Dlatego można uznać, że w tym aspekcie osoba w pełni sprawna niczym nie różni się od osoby niepełnosprawnej.

Do określenia sytuacji osób niepełnosprawnych, oprócz terminu stygmatyzacja, używa się również pojęcia dyskryminacji. Uwarunkowania związane z pierwszym zjawiskiem są przyczyną tego drugiego, ponieważ określają, w jaki sposób tworzą się sytuacje dyskryminacyjne. Wszystkie te pojęcia określają osoby niepelnosprawne jako mniejszość, która nie spełnia norm przyjętych przez ogół zbiorowości.

Zjawisko wykluczenia społecznego, którejest wynikiem oddziaływań zjawisk opisanych powyżej - od stereotypizacji, przez stygmatyzację, po dyskryminację - w naukach socjologicznych jako pierwszy opisał Georg Simmel. Twierdził, że problem „oddzielenia populacji wykluczonych i niewykluczonych, pozostaje zawsze arbitralna, a prawdziwym problemem nie jest charakterystyka czy oszacowanie liczby wykluczonych, lecz relacje współzależności i działania” (cytat za: Damon 2012, s. 23). W termin wykluczenie wpisane są pytania - kto i przez kogo został wykluczony oraz w jakim aspekcie, w jakiej dziedzinie życia społecznego do tego doszło. Kolejną obserwacją Simmla było to, że w żadnym narodzie nie istnieje określona zbiorowość, która byłaby zupełnie, w sposób jednoznaczny wyłączona poza margines społeczeństwa. Oznacza to tyle, że jednostka nie może być wykluczona ze wszystkich zbiorowości z powodu pełnienia w życiu wielu ról społecznych. 
Funkcjonujący w społeczeństwie wizerunek osób niepełnosprawnych utrudnia lub ułatwia ludziom dostosowanie się do własnych ograniczeń. Pozytywny obraz zwraca uwagę na dodatnie przymioty i możliwości osoby, zaś negatywny wizerunek - powoduje wzmacnianie jej ograniczeń. Nie ma to obojętnego wpływu na jej samoocenę, samoakceptację orazjakość życia (Mercer, Barnes 2008).

Zjednej strony w dyskursie publicznym widoczne są postulaty różnych opiniotwórczych środowisk, które wymagają budowania poprawnego wizerunku osób niepełnosprawnych.

Z drugiej zaś w przestrzeni medialnej ukazany jest obraz budzący raczej tanią sensację niż przedstawienie prawdziwej opowieści o życiu takich osób. Zgeneralizowany obraz osoby niepełnosprawnej pełny jest przede wszystkim beznadziei, cierpienia, ubóstwa, apeli o pomoc, zbiórek publicznych na operację. Aby spowodować u odbiorcy współczucie, oburzenie czy litość, następuje duże skoncentrowanie niepełnosprawności (Zakrzewska-Manterys, Niedbalski 2018).

Obok tak dramatycznego obrazu niepełnosprawności, media pokazują także te postacie, które niejako przecząc własnym ograniczeniom, pokazują światu realne możliwości osób niepełnosprawnych ${ }^{4}$.

Postulowany wizerunek niepełnosprawności

Społeczne definiowane inności osób z niepełnosprawnością odbywa się z udziałem elit symbolicznych i tworzy idealny obraz niepelnosprawności. J est on konstruowany w znaczeniu normatywnym poprzez akty legislacyjne czy definicje regionów dóbr osobistych, wyróżniając w nich szczególnie godność człowieka. Termin elity symboliczne wprowadził do nauki, w postaci swoistej koncepcji, Teuna A. van Dijk, będący pod dużym

\footnotetext{
4 Takim przykładem może być wyczyn Jana Meli. Stracił on obie kończyny i porusza się dzięki protezom, a jednak jest najmłodszym zdobywcą obu biegunów Ziemi i to w ciągu jednego roku. Było to osiągnięcie bardzo szeroko komentowane przez media.
} 
wpływem teorii socjologicznych formułowanych przez Pierre’a Bourdieu. Według tego autora do grupy społecznej elit symbolicznych należy zaliczyć ekspertów, publicystów, dziennikarzy, redaktorów, pisarzy, autorów podręczników szkolnych, duchowieństwo, naukowców, ludzi biznesu, intelektualistów oraz występujących w massmediach polityków (Czyżewski et al. 2014).

Ta szczególna grupa pełni ważną rolę w ustalaniu tego, co jest ważne i moralne. Wpływa też znacząco na definiowanie stanowisk naukowych. Do tej grupy społecznej należą także ci, którzy niejako aspirują do tego, aby kulturowo kontrolować dyskurs w sferze publicznej. „Rzadko zauważa się bowiem, iż do dyskursu elit symbolicznych należy zdecydowana większość przekazów medialnych - wypowiedzi «szarych» obywateli pojawiające się w środkach masowego przekazu (na przykład w reportażach, sondach ulicznych, programach typu talk show czy poszukujących nowych talentów formatach rozrywkowych)" (Ibidem, s. 9). Należy podkreślić, że pojęcie elit symbolicznych nie odnosi się do zjawiska władzy politycznej, lecz do władzy w sferze symbolicznej. Zatem analizowane przekazy płynące do społeczeństwa będą obejmowały dość szeroki zakres nadawców.

Elity symboliczne mają swój udział w formułowaniu zaleceń oraz postulatów dotyczących idealnego wizerunku osób z niepelnosprawnościami. Opis tego obrazu konstytuuje się szczególnie dobitnie w formie aktu prawnego w postaci Konwencji o prawach osób niepełnosprawnych, ale również w zbiorze zasad wydanych przez Polską Radę Etyki Mediów.

Pierwszy z tych dokumentów w rozdziale 8. daje doniosły przekaz, że wizerunek osób niepełnosprawnych jest ważny i należy o niego aktywnie zabiegać np. tworząc kampanie medialne. Istotne staje się wzmacnianie poszanowania prawi godności tej grupy osób, która zyskuje podmiotowość (Zgromadzenie Ogólne Narodów Zjednoczonych 2006).

Politycy, wykorzystując narzędzie aktu normatywnego, zakazali dyskryminacji, a ponadto wzmocnili postulat promocji pozytywnego 
wizerunku osób niepełnosprawnych, który będzie pełniejszy dzięki wiedzy o zdolnościach i wkładzie tej grupy w rozwój społeczeństwa. „Trzeba pokazywać tych ludzi w normalnych sytuacjach społecznych, akcentować ich ludzkie możliwości jako obywateli mających równe prawa, choć nierówne szanse. Trzeba, aby zobaczono ich jako ludzi aktywnych wnoszących swój wkład w dobro wspólne” (Rada Etyki Mediów 2003). Powyższymi słowami, w postaci apelu, zwróciła się do publicystów Polska Rada Etyki Mediów. Głównym postulatem apelu miało być przeciwdziałanie krzywdzącym stereotypom.

Przykładem innych postulatów, wynikających z etyki dziennikarskiej, są zalecenia dla ludzi mediów mówiące o pracy z osobami niepełnosprawnymi. „Szacunek dla osób. [...] Dziennikarz zachowuje szczególną wrażliwość w kontakcie z osobami niepelnosprawnymi, dotkniętymi inną chorobą, a także pozostającymi w ubóstwie" (Murawska-Najmiec 2006, s. 35). J est to jeden z elementów, który składa się na system ochrony etyki dziennikarskiej w Polsce. Został on przywołany, aby podkreślić, że temat niepełnosprawności jest obecny w zaleceniach dla przedstawicieli „Czwartej władzy”. Podobne zasady mają poszczególne stacje telewizyjne, rozgłośnie radiowe, redakcje prasowe, ale pomimo dość precyzyjnie sformułowanych zaleceń wdrażanie ich w codzienną praktykę pracy dziennikarskiej nie jest proste. Praca żurnalisty podlega trudnym prawom rynku medialnego, który wymaga, w drodze uproszczeń i segregowania rzeczywistości, dostarczania „taniej sensacji”.

Poniżej zestawiono postulaty, które mają na celu budowanie pozytywnego wizerunku osób z niepelnosprawnościami. Zostały one odtworzone na podstawie analizowanych źródeł oraz sugestii badaczy zjawiska niepełnosprawności (Struck-Peregończyk, Kurek-Ochmańska 2018):

- Sposób przedstawienia osób niepełnosprawnych powinien ukazać ich jako członków społeczeństwa włączonych w główny nurt polityk państwa. 
- Należy zauważyć, że nie ma naturalnie pozytywnego wizerunku niepełnosprawności, dlatego powinien on podlegać świadomej kreacji (Shearer 2002).

- W powstającym przekazie medialnym należy niwelować ukazywanie osób niepelnosprawnych ze stygmatem uzależnienia od innych (Sadowska 2005).

- Tworzony wizerunek powinien uwzględniać przekaz, że niepełnosprawność niejest immamentną cechą człowieka, ale również wynika z barier obecnych w otoczeniu (Barnes 1997).

- Osoby niepelnosprawne powinny być przedstawiane jako zwyczajni ludzie, bez nadmiernego pokazywania ograniczeń ciała i jego niesprawności lub przeciwnie - jako osoby o nadzwyczajnych zdolnościach; są to skrajności, które nie obrazują prawdziwego wizerunku.

- Należy prezentować osoby z niepelnosprawnościami jako uczestników życia publicznego, którzy mają prawa gwarantowane między innymi Konstytucją RP czy konwencjami, do udziału we wszystkich przejawach życia społecznego (równość).

- J ednostronne przedstawianie nowych technologii w życiu osób niepełnosprawnych jako rozwiązania wystarczającego do całkowitego zniesienia problemów z barierami, jest mylące. Może wprowadzić społeczeństwo w przekonanie, że zaopatrzenie tej grupy osób w specjalistyczny sprzęt oraz dostęp do Internetu zneutralizuje kłopoty związane z niepełnosprawnością (Masłyk, Migaczewska, Stojkow, Żuchowska-Skiba 2016).

- Powinno się przedstawiać osoby z niepełnosprawnością w sytuacjach codziennych, bez łączenia ich życia z konieczną dobroczynnością organizacji charytatywnych (Barnes 1997).

- Przekazy medialne powinny unikać ukazywania osób niepełnosprawnych jako środowiska homogenicznego. Programy i artykuły powinny uwzględniać różnorodność potrzeb ze względu na 
rodzaj i przyczynę niepełnosprawności (Zakrzewska-Manterys 2003).

- Należy uznać za regułę, że w przypadku programów emitowanych w telewizji czy w filmach w rolach postaci niepełnosprawnych powinny być obsadzane osoby z niepełnosprawnościami (Stanisławski 2003).

- Publicyści i dziennikarze powinni mieć świadomość wpływu wykorzystywanego języka na opisywanie rzeczywistości osób niepelnosprawnych. Sformułowania medykalizujące stygmatyzują tę grupę osób (Barnes 1997);

- Osoby niepełnosprawne, również ze względu na swoją liczebność są znaczącą siłą nabywczą. Warto jest pokazać ich pozycję w przestrzeni konsumenckiej (rynek, handel).

- Materiały i przekazy medialne dotyczące osób niepełnosprawnych powinny być konsultowane ze środowiskiem tych właśnie osób (Barnes 1997).

Klamrą tych wszystkich postulatów jest stwierdzenie, że osoba niepelnosprawna jest pełnoprawnym członkiem społeczeństwa, ma równe prawa i szanse w realizowaniu swoich potrzeb oraz aspiracji.

Metodologia badań

Przedstawiony problem badawczy dotyczy opisu zjawiska społecznego, jakim jest konstruowanie wizerunku określonej grupy społecznej. Krzysztof Konecki (2016) wskazuje, że socjologia jakościowa koncentruje się na właśnie takiej orientacji, wzbogaconej o rozumienie oraz wyjaśnianie. Takie podejście, w wyniku badań empirycznych i analizy doświadczeń indywidualnych oraz w odniesieniu do zbiorowości, dostarcza narzędzi do formułowania definicji światów społecznych i zachodzących w nich oddziaływań.

Pomimo narastającej presji obrazu jako źródła informacji i wspierających go nowych technologii, słowo pisane nadal pozostaje podstawową 
metodą komunikowania. Zatem jakościowa analiza treści, w postaci tekstów, będzie drogą do uzyskania odpowiedzi na pytania badawcze. Analiza treści jest rozumiejącą, usystematyzowaną i z założenia analityczną lekturą przekazów (Szczepaniak 2012). Wybrana metoda badawcza nie wymaga bezpośredniego kontaktu badającego z badanym, ponieważ badacz operuje na materiałach już gotowych.

Należy wspomnieć także o zasobie wiedzy badacza na określony temat oraz jego intencjach w czasie opracowania wyników badań. To w połączeniu z przekonaniami autora może oddziaływać na końcowe wnioski, mimo wysiłku wkładanego wintersubiektywność prowadzonej analizy. Z tym spostrzeżeniem powiązane jest zjawisko refleksyjności, obecne w jakościowej analizie danych. Oznacza ono konieczność przyjęcia faktu, że wnioski z badań, w zdeterminowany sposób, są odbiciem wykształcenia, otoczenia i preferencji osoby przeprowadzającej badania Graham Gibbs, rozpatrując zagadnienia jakości i etyki badań, zauważa, że „badacze jakościowi - podobnie zresztą jak inni naukowcy - nie mogą twierdzić, że są obiektywnymi, miarodajnymi, politycznie neutralnymi, zewnętrznymi obserwatorami rzeczywistości, niezaangażowanymi w treść przedstawianych przez siebie raportów badawczych" (Gibbs 2011, s. 164).

Definicji Bernarda Berelsona zakłada, że badacz będzie dokonywał analizy wyłącznie jawnej zawartości komunikatów. Widoczne jest tam również założenie, żeznaczenie przekazywanej treści jest zawsze zgodne z intencją jej nadawcy. Przyjęcie bezwzględnie literalnego odczytywania treści powodowałoby, że analiza treści byłaby z gruntu płytka. Zatem, aby tego uniknąć, pozwala się, aby badacz mógł sam wyciągać wnioski, zaś za istotne uważa się przejrzystość i klarowność tego procesu swojej interpretacji. Wnioski zatem mogą dotyczyć tego co zostało napisane, ale również tego co zostało intencjonalnie pominięte. Karolina Szczepaniak podkreśla również, że analiza treści nie jest tylko wnioskowaniem badacza na temat badanego materiału. W procesie tym zachodzą róż- 
nego rodzaju interakcje. Widoczne są one między zasobem wiedzy autora, analizy na dany temat, jego dotychczasowymi doświadczeniami oraz intencjami autora analizy, prowadzącymi do powstania treści (Szczepaniak 2012).

Biorąc pod uwagę te zależności w analizie treści artykułów, wypowiedzi dziennikarskich oraz tekstów o charakterze publicystycznym, autor artykułu dokonał rewizji kształtowanego wizerunku osób niepełnosprawnych w mediach. Ze względu na niejednokrotnie subtelny - czasami nie wprost - sposób prowadzonego dyskursu, badaniu podlegał między innymi dobór osób, jaki został dokonywany przez żurnalistów. Uwzględnione będzie również to, że bohaterowie wywiadów, reportaży, goście studiów radiowych wyrażają swoje opinie w oparciu o reprezentowany przez nich światopogląd.

Do analizy badawczej wybrano następujące tytuły z rynku wydawniczego w Polsce w kategorii tygodników opiniotwórczych: „Newsweek”, „Polityka” i „Wprost”. Są to periodyki o ugruntowanej pozycji w grupie polskich czytelników. Wśród rankingów sprzedaży w ogólnej grupie odbiorców trzy pierwsze miejsca zajmują „Newsweek” z wynikiem 2,9\%, „Polityka” - 2,6\% oraz „Gość Niedzielny” - 2\%. J ednak jeśli zostaną wprowadzone dodatkowe kryteria, zawężające grono czytelników do osób ze średnim i wyższym wykształceniem oraz tych, których dochód gospodarstw domowych wynosi powyżej 5 tys. zł netto, to tygodnikami najczęściej kupowanymi są nadal „Newsweek” oraz „Polityka”. J ednak trzecie miejsce w rankingu sprzedaży zajmuje tygodnik „Wprost” ( „Newsweek” - 4,5\%, „Polityka” - 3,6\%, „Wprost” - 2\%)

Konstrukcja profilu demograficzno-społecznego czytelników wskazanych tygodników może dać podstawę do stwierdzenia, że korzystając ze swojej elitarnej pozycji periodyki te mają wpływ na opinie swoich odbiorców. Robiąc założenia do badań uznano, że czytelnicy tych tygodni-

5 Sierpień 2018-styczeń 2019; CPW; grupa celowa: osoby w wieku 15-75 lat, N=9 899 (Polskie Badania Czytelnictwa 2019). 
ków pełnią funkcję liderów - przekaźników, a więc rozpowszechniają wizerunek niepełnosprawności prezentowany w wymienionych mediach. To właśnie najpierw do tych osób docierają informacje, interpretacje wydarzeń, komentarze. I dalej, zgodnie z teorią dwustopniowego przepływu informacji, rozpowszechniane są one do osób mniej aktywnych medialnie (Esparcia, Smolak-Lozano 2012).

Badanie tekstów zostało oparte o ustalone apriorycznie kategorie badawcze w taki sposób, aby zrekonstruować prezentowany w artykułach wizerunek osób z niepełnosprawnościami czy zjawiska niepelnosprawności. W trakcie analizy zwrócono zatem uwagę na następujące kwestie:

- zrekonstruowanie ról społecznych osób niepełnosprawnych ukazanych w artykułach,

- ukazanie wybranych aspektów życia codziennego bohaterów artykułów,

- intencjonalną działalność osób niepełnosprawnych skierowaną na poprawę wizerunku osób niepełnosprawnych,

- sposób prezentowania aktywności zawodowej i społecznej przedstawiony w artykułach,

- nacechowanie emocjonalne tekstów artykułów,

- poziom wpływu aktualnych wydarzeń politycznych, społecznych, gospodarczych na funkcjonowanie osób z niepełnosprawnościami,

- język i pojęcia, jakie są używane do opisu zjawiska niepełnosprawności oraz osób niepełnosprawnych, występowanie określeń o wydźwięku negatywnym oraz cel ich używania,

- przyjęty sposób narracji w opisie osób z niepelnosprawnościami,

- nadawcy przekazów, które dotyczyły osób niepełnosprawnych. Kwerenda obejmująca archiwalne wydania trzech tygodników: „Newsweek”, „Polityka” oraz „Wprost” w okresie jednego roku od 1 kwietnia 2017 do 31 marca 2018 roku wykazała 46 artykułów, w których została poruszona tematyka niepelnosprawności. Przy czym do analizy nie były kwalifikowane te materiały, które tylko wzmiankowały tematykę osób 
niepełnosprawnych. Dokonująckwerendy nie zauważono, aby którykolwiek z tygodników publikował znacząco więcej artykułów o tematyce niepełnosprawności niż pozostałe periodyki (,Wprost” - 15 artykułów, „Newsweek” - 15 artykułów, „Polityka” - 16 artykułów).

Przyjęto założenie, że okres jednego roku będzie wystarczający, aby podjąć próbę rekonstrukcji wizerunku osób z niepełnosprawnościami. Natomiast decyzja o wyborze tego właśnie przedziału objętego określonymi terminami, wynikała z wydarzenia, jakie miało miejsce w Sejmie RP 18 kwietnia 2018 roku. Doszło wówczas do podjęcia protestu rodziców osób niepełnosprawnych. Było to wydarzenie, które wywołało żywiołową i emocjonalną dyskusję w sferze publicznej. Protestem rodziców intensywnieinteresowały się media w Polsce. Temat zjawiska niepelnosprawności stał się wówczas problemem podejmowanym na szeroką skalę. Dlatego, aby ograniczyć wpływ tego szczególnego wydarzenia na dyskurs publiczny dotyczący niepelnosprawności, zakres czasowy, którego dotyczy badanie, nie obejmuje okresu, w którym trwały protesty w Sejmie RP. Warto jest również dodać, że redakcje tygodników, które były poddane analizie, swoje profile polityczne określają jako liberalno-konserwatywne, liberalno-lewicowe lub lewicowe. Cechą wspólną tych periodyków jest brak spójności z wykładnią polityczną obozu rządzącego w okresie poddanym badaniu (lata 2017/ 2018).

Główną tezą postawioną w badaniu jest stwierdzenie, że wizerunek osób z niepełnosprawnością kreowany w tygodnikach opinii jest oparty przede wszystkim na obrazie: inności, nędzy, zależności, opiekuńczości, charytatywności, roszczeniowości, ponadprzeciętności.

Analiza materiału badawczego

- rzeczywisty obraz osób niepełnosprawnych

W analizowanych tekstach osoby niepełnosprawne pokazywane są zatem w sposób niehomogeniczny, w wielowątkowych sytuacjach społecznych, o zróżnicowanych narracjach oraz ich nacechowaniu emocjonalnym 
czy wielu rolach społecznych. Największa część analizowanych tekstów ukazuje osoby niepełnosprawne w roli osób chorych, pacjentów [3, 6, 14, 22, 26, 29, 30, 32, 42, 44] ${ }^{6}$ oraz osób starszych, seniorów, osób zależnych, klientów pomocy społecznej [5, 11, 16, 21, 23, 25, 27, 28, 31, 42, 46]. Osoby niepelnosprawne w artykułach ukazywane są również w roli pracowników, którzy są zadowoleni ze swojej pracy [4] albo ogólnie w kontekście rynku pracy [2, 10, 43]. Kolejną rolą utrwaloną w artykułach jest: uczeń wsystemie edukacji [12, 34], ojciec, zmagający się ze zjawiskiem wykluczenia [35], niepełnosprawny wyborca [9], ofiara przemocy seksualnej [33], odbiorca oferty kulturalnej [39], aktor [20, 40] czy matka opisująca doświadczenie macierzyństwa i jej pragnienia, aby syn „nie wstydził się swojej mamy” [40]. Ważnejest to, żejedna osoba, którą opisuje się wartykule, wypełnia często kilka ról społecznych jednocześnie. Przykładem jest opowieść matki o jej 18-letnim synu, który jest głuchoniewidomym mężczyzną, dotkniętym dodatkowymi sprzężonymi schorzeniami. Bohater reportażu przedstawiony jest w co najmniej trzech rolach: syna, pacjenta, podopiecznego [45].

Część artykułów stawia osoby niepełnosprawne w pozycji ludzi wyjątkowych. Znakomitym przykładem jest Monika Kuszyńska była wokalistka zespołu „Varius Manx”, która uległa wypadkowi i obecnie porusza się na wózku inwalidzkim. Prestiżu dodaje jej sława artystyczna, natomiast atrybut niepełnosprawności zostaje wykorzystany do reklamy rajstop [41]. W kolejnej roli, jaką jest pracownik naukowy, ukazano Stephena Hawkinga, jako geniusza fizyki, „uwięzionego w bezwładnym ciele”, zaś „ludzie niezwiązani z fizyką zwykle bardziej cenili go za hart ducha niż osiągnięcia w pracy naukowej" [13]. Kolejnym przedstawionym przypadkiem „superkaleki”, czyli osoby z niepełnosprawnością o nadzwyczajnych zdolnościach, jest Lenin Moreno. J est on „jedynym przywódcą państwowym na wózku inwalidzkim. Być możejedynym od czasów Franklina Delano Roosevelta”. W roku 2017 został wybrany na prezydenta Ekwadoru [19]. Przy tej okazji warto jest wspomnieć o roli,

${ }^{6}$ Oznaczenie cyfrowe - odwołania do artykułów wyszczególnionych w spisie na końcu artykułu. 
jaką odegrał były prezydent Stanów Zjednoczonych w kształtowaniu medialnego wizerunków osób z niepełnosprawnością. Należy podkreślić, że niewiele jest zdjęć, które przedstawiają jego postać na wózku inwalidzkim. Z tego wynika, żeatrakcyjność fizyczna i sprawność to ważne cechy w ubieganiu się o fotel prezydenta USA.

Ten przykład oraz prezydenta Ekwadoru potwierdza, że niepełnosprawność nie jest przeszkodą do osiągania sukcesów, jednak jest czymś stygmatyzującym, zaś piętno trzeba ukrywać, aby nie przeszkadzało w normalnym życiu (Struck-Peregończyk 2013). Do tych niezwykłych niepelnosprawnych bohaterów pelniących rolę artystki estradowej, pracownika naukowego, polityka, można również dodać przedsiębiorcę. J est nim Adrian Furman - „twórca agencji e-kreacji (Grupa AF sp. z o.o.), w której zatrudnia 18 osób z niepelnosprawnością, dając im możliwość re habilitacji zawodowej i konkurowania na otwartym rynku branży IT" [1].

Autor na podstawie analizy literatury wyróżnia dwa sposoby przedstawiania osób z niepełnosprawnościami - jako ofiarę lub jako superbohatera. Takie spostrzeżenieniejest spójne z postulatami dotyczącymi prezentowania wizerunku tych osób. Tworzony wizerunek powinien uwzględniać przekaz, żeniepelnosprawność niejest immamentną cechą człowieka, ale również wynika z barier obecnych w otoczeniu. Powinien także odnosić się do drugiego postulatu, który określa, że osoby niepelnosprawne należy przedstawiać jako zwyczajnych ludzi. Ta dychotomia powoduje wewnętrzny konflikt we własnym rozumieniu tożsamości osób niepełnosprawnych. Widać to w wystąpieniu Stelli Young, która sama będąc osobą niepelnosprawną, uważa, że spoleczeństwo uprzedmiatawia niepelnosprawność czyniąc z niej „,inspiracyjne porno”. Rzecz, zjawisko, które ma pomóc pełnosprawnej części społeczeństwa, ma się stać motywacją z refleksją na końcu: „Nieważne, jak jest źle, mi w życiu mogłoby być gorzej” (Young 2014). 
Analizie poddano również język, pojęcia, jakie są używane do opisu zjawiska niepełno-sprawności oraz osób niepełnosprawnych. Wykorzystane słowa, które jednak często są wynikiem uogólnien, wpływały na nacechowanie emocjonalne tekstów artykułów.

Określenia osób niepełnosprawnych jakie pojawiły się w analizowanych tekstach, zazwyczaj miały wydźwięk pejoratywny. Odwoływały się raczej do cech negatywnych, a używane słowa były zwyczajnie obraźliwe. Do opisu osób niepelnosprawnych były używane takie słowa: „debil”, „potwór”, „ułomek”. Są to określenia wyraźnie deprecjonujące.

Analiza tekstów artykułów wskazuje, że często ich autorzy w opisie odnoszą się do występujących dysfunkcji: „ów eksprzedsiębiorca bez władzy w nogach”, spotkanie z „przywódcą państwowym na wózku inwalidzkim” [19], odniesienie do „niepełnosprawnych, obciążonych różnymi schorzeniami” [30] czy „wizja starości spędzonej na wózku inwalidzkim, z paraliżem, powykręcanymi chorobą stawami i koniecznością korzystania z butli z tlenem" [25]. Są to określenia, które mogą wywoływać u odbiorcy takich tekstów negatywne emocje, przestrach, a nawet obrzydzenie.

W jednym z tekstów obecne jest wskazanie na niedobór określonych zmysłów - ,jest osobą głuchoniewidomą ze sprzężeniami” [45]. Ta właśnie osoba z jednoczesnym uszkodzeniem narządu słuchu i wzroku jest uczniem [12]. W jednym z artykułów czytelnik poznaje stosunek senatora Stanisława Koguta do osób, którymi zajmuje się jego fundacja. Podejście tego polityka do osób niepełnosprawnych intelektualnie autor artykułu przedstawia w stosowanym słownictwie, które powinno podlegać krytyce społecznej. Tytułowy „Anioł Stróż” określa swoich podopiecznych mianem „ułomków”.

J ęzyk, w szczególności opisujący osoby z niepelnosprawnością intelektualną, „(..) niejako uromantyczniono. Dla większości Polaków oznacza dziś pogodną, przyjacielską osobę «misiaczka»” [4]. Takie zjawisko wskazuje na pewną pobłażliwość, zaś używanie zdrobnień językowych, 
bardziej właściwych do nazwania zabawki dziecięcej, powoduje właśnie infantylizację dorosłych osób, choć z niepelnosprawnością intelektualną.

W innym artykule autor recenzji filmu Happy end Michaela Hanekego przywołuje jedną ze scen, kiedy to osoba niepełnosprawna, senior na wózku inwalidzkim, zjeżdża do wody, aby skończyć ze swoim „niepełnosprawnym życiem”. Ten zwrot wskazuje na egzystencję osoby niepełnosprawnej jako gorszej, której koniec jest zwieńczeniem udręki.

Przechodząc do wątku ukazanych przejawów życia codziennego osób z niepełnosprawnościami, odniesienia na ten temat można odnaleźć w 15 tekstach z 46 przeanalizowanych artykułów. Ukazują one rzeczywistość obarczoną różnymi problemami, które powodują niepełnosprawność.

J edną z takich historii opowiada artykuł na temat osoby, która przeszła amputację kończyny górnej. Bardzo ważne jest dla niej to, aby jak najszybciej otrzymała odpowiednią protezę. J ednak nie jest to proste, skoro po ogłoszeniu informatyka z Warszawy o możliwości nieodpłatnego przekazania protezy „skontaktowało się z nim w kilka dni ponad 100 osób” [29]. Wynalazca, dzięki swoim innowacyjnym umiejętnościom technologicznym, pomaga osobom niepelnosprawnym. Sytuacja ta odsłania bardzo duże niedobory w zaopatrzeniu w przedmioty ortopedyczne. Analiza obecnego systemu zaopatrzenia w przedmioty ortopedyczne oraz środki pomocnicze wskazuje na to, że wsparcie w tym zakresie powinno być domeną państwową (Minister Zdrowia 2019). Bohater artykułu mówi, że „(...) to, co rozdaje, to nie są protezy. Proteza to wyrób medyczny, z certyfikatami. My robimy model ręki 3D, który ułatwia rehabilitację i codzienne funkcjonowanie”. Tym sposobem czytelnik dowiaduje się, że nowoczesne technologie, choć są olbrzymią szansą, to jednak nie zaspokajają wszystkich potrzeb osób po amputacjach [29].

Bohaterami artykułów są również opiekunowie osób niepełnosprawnych. W analizowanych artykułach ich codzienność wypełniają czynności pielęgnacyjne czy dbałość o rehabilitację podopiecznych. W jednym 
z nich pokazane jest trudne funkcjonowanie chorych dzieci w szkole „swędzenie nasila się, nie sposób usiedzieć, chory drapie się do krwi. Ulgę przynoszą kąpiele, smarowanie maścią" [34]. W drugim artykule zostaje wnikliwie podana przyczyna niepełnosprawności oraz występujące sprzężenia chorobowe podopiecznego. Dalej szczegółowo pokazana jest złożona i wyczerpująca ścieżka koniecznych zabiegów rehabilitacyjnych: „zajęcia ze słuchu, głosu i mowy, zajęcia z brajla i orientacji przestrzennej, warsztaty terapeutyczno-teatralne, nauka języka migowego, zajęcia arteterapeutyczne" [45]. Takie świadczenia to także wysiłek finansowy, który dla rodziny jest trudny do udźwignięcia.

Problem pauperyzacji środowiska osób niepelnosprawnych i ich rodzin jest tematem kolejnego artykułu, w którym matka z córką chorą na porażenie mózgowe „żyją z tysiąca złotych jej emerytury i ze 153 zł zasiłku pielęgnacyjnego" [14]. Natomiast w wywiadzie z Filipem Chajzerem pokazana jest historia niepelnosprawnego uczestnika teleturnieju, który był „bardzo biednym łodzianinem”. Zubożenie jest także opisaną przyczyną charytatywnych gestów wobec osób niepelnosprawnych [7].

Osoby niepełnosprawne dotknięte deficytami ciała, bądź o mniejszych zdolnościach poznawczych, w swojej codzienności nie tylko zmagają się z ograniczeniami wynikającymi z niepełnosprawności, ale również mają trudności związane z zapewnieniem środków do życia. Praca dla jednej grupy osób z niepelnosprawnościami stanowi przede wszystkim źródło utrzymania, dla drugiej jest przyczyną satysfakcji i samorealizacji (Szymańska 2018). J ednak bez względu na motywacje podjęcia zatrudnienia, od wielu lat w Polsce notowany jest niski poziom aktywności zawodowej, o wiele niższy od tego dotyczącego osób sprawnych77.

O aktywności zawodowej osób niepełnosprawnych można przeczytać w 8 przeanalizowanych artykułach. Zawierają one przede wszystkim opisy problemów, z jakimi mierzą się osoby niepelnosprawne chcące

7 W IV kwartale 2018 r. wskaźnik zatrudnienia osób z niepełnosprawnościami w wieku 16 lat i więcej oraz w wieku produkcyjnym (18-59/64) wynosił 28,3\%, natomiast dla części sprawnej społeczeństwa był trzykrotnie wyższy - 77,5\% (Biuro Pełnomocnika Rządu ds. Osób Niepełnosprawnych 2018). 
podjąć pracę. Można z nich wywnioskować, że sytuacja zawodowa osób niepełnosprawnych w niektórych częściach kraju jest zła - brakuje dla nich pracy.

J ednak prawne usankcjonowanie niepelnosprawności (orzeczenie lekarskie) daje zatrudnienie, staje się przepustką do pracy dla tych, których predyspozycje społeczno-zawodowe (np. wykształcenie, staż pracy) są gorzej oceniane ze względu na posiadane deficyty. Bohater jednego z artykułów i jego rodzina „zarabia na życie w zakładach, które dostają premie z Państwowego Funduszu Rehabilitacji Osób Niepełnosprawnych za zatrudnianie niepelnosprawnych" [15]. Opisana w tekście sytuacja uwidacznia zjawisko poziomej segregacji zawodowej, która oprócz koncentracji aktywności zawodowej w określonych profesjach grupy dyskryminowanej (Kalinowska-Sufinowicz 2017), powoduje stłoczenie osób niepełnosprawnych w określonych miejscach zatrudniania (zakłady pracy chronionej, zakłady aktywności zawodowej).

W analizowanym materiale znalazły się również dwa artykuły, w których przedstawiono pozytywne przykłady związane z życiem zawodowym pracowników z niepelnosprawnościami. Ukazanym wjednym z nich przykładem sukcesu ekonomii społecznej jest browar w Pucku, który zatrudnia osoby z niepełnosprawnością intelektualną. Aspiracje tych osób do udziału w rynku pracy były wcześniej przedmiotem drwin, jednak z czasem udowodnili swoją przydatność wynikiem finansowym bliskim 2 milionów złotych (Molga 2018). Agnieszka Dejna, laureatka nagrody tygodnika „Newsweek” - Społecznik Roku 2017 - która zakładała przedsiębiorstwo, mówi że „udało się przywrócić im godność, o którą trudno, gdy się pobiera zasilki” [2].

Osoby z niepełnosprawnościami chcą być oraz są aktywnymi uczestnikami życia społecznego. Jako takie zostały przedstawione w 5 z 46 przeanalizowanych artykułów. W omawianych tekstach można przeczytać o aktywności tych osób w różnych dziedzinach: show biznesie [41], świecie nauk ścisłych [13], organizacji pozarządowej [40], organizowa- 
niu gier - larpów [28], polityki [19], działalności biznesowej [1]. Bohaterowie każdego z tych artykułów w świadomy sposób kreują rzeczywistość związaną z obrazem niepełnosprawności. Ma to duże znaczenie dla uwiarygodniania pozytywnego wizerunku, ponieważ przykład własny jest najbardziej przekonywujący.

W analizowanych tekstach można wyróżnić dwa typy przekazów. Pierwszy pokazuje osoby, które nie ogniskują na sobie uwagi szerokiej publiczności. Ich świat wydaje się pospolity, zwyczajny. J ednak drugi wskazuje na osoby znane i obecne w mediach, które odgrywają ważne role w działaniach na rzecz środowiska osób niepelnosprawnych. J edną z takich postaci jest Stephen Hawking, geniusz- naukowiec, autor bestsellerów literackich, gwiazda filmu StarTrek, który będąc punktem odniesienia dla wielu osób niepełnosprawnych, mówi: „Choć sława ma swoje blaski i cienie, to zdecydowanie daje możliwość niesienia pomocy innym niepelnosprawnym" [13].

Źródłem relacji, informacji, opinii, przekonań czy sądów na temat osób $\mathrm{z}$ niepełnosprawnościami są $\mathrm{w}$ analizowanych tekstach różne osoby oraz przedstawiciele rozlicznych grup społecznych i zawodowych, począwszy od osób, których można określić mianem „zwykłych ludzi”. To właśnie oni opowiadają o swoich problemach bardzo szczerze i otwarcie przekazują swój punkt widzenia o osobach, którymi przyszło się im opiekować [14, 37].

Inną grupą biorącą udział wdyskusji nad zjawiskiem niepelnosprawności są naukowcy: kulturoznawca, który ocenia kampanię społeczną antyaborcyjną [42]; demografowie, którzy alarmują o przyroście liczby osób niepełnosprawnych [16]; socjologowie, opisujący przejawy kulturowego ateizmu [31, 11]; pedagog specjalna, która mówi o problemie wykorzystywania seksualnego osób z niepelnosprawnością intelektualną [33]; ekonomiści [11]; środowisko naukowe Gdańskiego Uniwersytetu Medycznego, które alarmuje wskazując na ograniczające sprawność skutki cukrzycy [25]; fizyk, który z swoim przekazem występuje jednocześnie w roli osoby niepełnosprawnej [13]. 
J ak pokazuje przykład wspomnianego fizyka, wartykułach podejmujących problematykę niepelnosprawności wypowiadają się również osoby z niepelnosprawnościami. W tej grupie nadawców, czyli osób $\mathrm{z}$ różnymi dysfunkcjami, jest również autor scenariusza do larpu. Twórca tej swoistej gry terenowej porusza się na wózku inwalidzkim i swoim pomysłem chce wywołać prawdziwą wewnętrzną zmianę w ludziach, którzy otworzą się na problematykę osób o szczególnych potrzebach [28]. W analizowanych tekstach występuje również niepelnosprawny przedsiębiorca, który osiągając znakomity wynik ekonomiczny swojej firmy, zabiera głos w ważnej sprawie społecznej - aborcji i eugeniki. Podkreślając swoją rolę w dyskusji wskazuje, że wypowiada się jako reprezentant „grupy najbardziej zainteresowanej - osób niepelnosprawnych" [1].

Kolejną grupą nadawców mówiących o osobach niepelnosprawnych w analizowanych tekstach byli politycy [3, 9, 19, 24], bądź osoby z otoczenia polityków oraz urzędnicy [5, 24,45]. Głos zabierają również pracownicy służby zdrowia [11, 22 ], a także reżyser filmowy, który na swoim przykładzie pokazuje zjawisko odrzucenia i wykluczenia z powodu piętna - szpetoty twarzy skaleczonej tragicznym wypadkiem [26].

Ważnymi uczestnikami dyskursu kształtującego obraz niepelnosprawności są pracodawcy. Kadry zarządzające, dyrektorzy działów HR dostrzegają potencjał w zatrudnianiu osób niepelnosprawnych. W swoich opiniach wystawiają wysoką ocenę tej grupie pracowników. Podkreślają przede wszystkim ich lojalność i zaangażowanie [8, 10]. Choć wjednym artykule pojawia się także krytyka tej quasi otwartości na pracowników z niepelnosprawnościami i jest podkreślana jej fasadowość, ponieważ faktyczne zatrudnianie rozmija się z deklaracjami [43]. Nieco inaczej wygląda sytuacja, gdzie osoby niepelnosprawne są współtwórcami miejsca pracy wówczas pracodawcy widzą bardziej świadomie wartość swoich pracowników [2, 4].

Oprócz opisanych powyżej nadawców przekazów dotyczących zjawiska niepelnosprawności można również wymienić: 
- dziennikarzy [7, 44, 46];

- rodziców dzieci z niepelnosprawnościami [12, 22, 34];

- rodziców z niepełnosprawnością [35, 40];

- inżynierów, konstruktorów [6, 29, 32, 38].

Spektrum uczestników dyskursu nad zjawiskiem niepełnosprawności w analizowanych artykułach jest zróżnicowane i obejmuje przedstawicieli różnych grup społecznych. Te zbiorowości nadawców przekazów, które są przedmiotem szczególnego zainteresowania niniejszego artykułu, czyli politycy, naukowcy i dziennikarze, są obecni w materiale badawczym. Żurnaliści są wprawdzie tylko zasygnalizowani na liście nadawców, jednak ich rola jest faktycznie obecna niemal w każdym z artykułów. Wynika to z tego, że jako autorzy tekstów mimochodem stawali się przekaźnikami, ale i aktywnymi twórcami treści. Znaczenie tych właśnie uczestników dyskusji, dotyczącej osób niepełnosprawnych, wiąże się z przedstawicielami elit symbolicznych, którzy formułowali postulaty dotyczące pożądanego wizerunku osób z niepelnosprawnościami.

Podsumowanie

Analiza materiału badawczego pozwala na sformułowanie stwierdzenia, że obraz obecny w mediach jest inny od tego postulowanego przez elity symboliczne. W większości artykułów osoby niepełnosprawne są ukazane w sytuacji niedostatku finansowego lub kłopotów zdrowotnych. Życie tej grupy osób, po lekturze wyselekcjonowanych artykułów, jawi się jako pasmo problemów, począwszy od braku dostępu do mieszkalnictwa komunalnego, po marginalizacje na rynku pracy.

Tymczasem postulowany wizerunek miał się opierać na wniosku z ważnej przesłanki, że osoby niepełnosprawne nie mają naturalnie pozytywnego obrazu w społeczeństwie. Zatem nawet jeśli najpierw zostaną ukazane negatywne zjawiska dotyczące sytuacji tej grupy ludzi, 
a następnie będą prezentowane w pozytywnie kojarzących się zdarzeniach, takich jak choćby pomaganie, to i tak będzie utrwalany pomniejszający wizerunek.

Wśród ważnych postulatów były także sugestie odejścia od opisywania ich w rolach osób uzależnionych od wsparcia. Zaprzestanie podkreślania obrazu codzienności naznaczonej niezbędną dobroczynnością innych jest również bardzo istotną przesłanką. Te wszystkie zjawiska niestety dominowały w analizowanych artykułach.

Dlatego właśnie w przeważającej większości analizowanych materiałów sytuacja tej grupy osób definiowana jest głównie poprzez role osób chorych - pacjentów, których trzeba leczyć. Powoduje to izolowanie, przynajmniej mentalne, osób z jakimiś dysfunkcjami. Skutki niepełnosprawności pokazywane są także w okolicznościach związanych z problemami transportowymi, trudnościami w dostępie do kultury czy niedostatecznej wydolności zaopatrywania przez państwo w protezy niezbędne do normalnego funkcjonowania. W wielu przypadkach niepełnosprawność jest nieodwracalna z powodów medycznych. Kontekst sytuacji indywidualnej prowadzi do przeświadczenia, że jest to ograniczenie niezbywalne i całościowo definiujące daną osobę.

Pomimo że sposób definiowania niepełnosprawności w aktach prawnych, opracowaniach naukowych, ale też i praktyce rewalidacyjnej ewoluuje - od modelu medycznego (indywidualnego), przez społeczny po funkcjonalny - to w analizowanych artykułach tygodników opiniotwórczych nadal wybrzmiewa model biologiczny. Przeważająca część opisów życia codziennego osób niepełnosprawnych w analizowanych tekstach ukazuje problemy z niesprawnością ciała.

Trzebajednak przyznać, iż są nieliczne artykuły wychodzące poza model charytatywno-opiekuńczy i ukazujące niwelowanie zewnętrznych ograniczeń oraz dostosowywanie otoczenia do możliwości osób z niepełnosprawnościami. Przykładem tego mogą być opisy działań PKP zmierzających do dostosowania infrastruktury kolejowej do potrzeb osób z niepełnosprawnościami [18]. 
Wizerunek jest więc odbiciem ludzkich przekonań. Dlatego za pomocą mediów można dotrzeć z tą prawdą do szerokiego grona odbiorców. Można pokazać obraz prawdziwy, odarty z uprzedzeń. Telewizja, prasa, radio czy Internet, odpowiadając na zapotrzebowanie swoich odbiorców, formułują przekaz oparty na prostych schematach. Te zaś prowadzą do powstawania stereotypów.

Nasuwa się tu jeszcze jedna refleksja: ci, którzy rzeczywiście dbają o pozytywny wizerunek osób niepełnosprawnych, to same osoby niepelnosprawne. Praca nad aprobującym obrazem jest ich świadomym działaniem. Mają poczucie, że ich starania skutkują poprawą sytuacji. J est to motywacja właściwa dla jednostek wyjątkowych, obdarzonych szczególnymi talentami, potencjałem intelektualnym, intuicją do biznesu. Można zatem przyjąć, że to właśnie te osoby, które są najbardziej zainteresowane pozytywnym wizerunkiem własnej grupy, w sposób świadomy budują jego dobry kształt. J ednak należy także zauważyć negatywną stronę tego zjawiska. Te wyjątkowejednostki ogniskują uwagę i kreują idealny, choć przecież fałszywy obraz niepełnosprawności. Ponadto obliguje on inne osoby niepełnosprawne do nadprzeciętności, co skutkuje warunkową akceptacją, a w rezultacie dyskryminuje (Podgórska-J achnik 2013).

Przejawami opiekuńczej funkcji państwa wobec osób niepełnosprawnych są między innymi: gwarancja edukacji, bezpłatnej służby zdrowia czy równego dostępu do rynku pracy. J ednak w analizowanych artykułach ukazane są niedobory w każdej z tych dziedzin. Na przykład zaopatrzenie w przedmioty ortopedyczne (protezy kończyn niezbędne do wykonywania codziennych czynności) jest pretekstem do pokazania zaangażowania nowych technologii w służbie osobom niepełnosprawnym, choć możliwości nowych rozwiązań przeważnie nie są w zasięgu możliwości nabywczych osób z niepełnosprawnościami, albo użycie nowych technologii nie powoduje całościowej redukcji skutków dysfunkcji. 
Dość ponurą konkluzją z przeprowadzanych badań jest widoczny brak pojednania tych dwóch porządków postrzegania osób niepelnosprawnych: stanu postulowanego i rzeczywistego wizerunku osób z niepełnosprawnościami kształtowanego przez media. Pomimo wysiłku wielu osób, mających na celu wdrożenie w życie przywołanych w opracowaniu postulatów, notorycznienie udaje się wprowadzić zmian w oczekiwanym przez ich autorów wymiarze. J ednak obserwując przekształcenia obrazu osób niepełnosprawnych w świecie massmediów na przestrzeni wielu lat, stwierdzić można , że choć postęp jest nieliniowy, to jednak jest dostrzegalny.

Literatura

Aronson, E., Wilson T.D., Akert, R. (1997). Psychologia społeczna. Serce i umyst. Poznań: Zysk i S-ka.

Baran, S.J., Davis, D.K. (2007). Teorie komunikowania masowego. Kraków: Wydawnictwo Uniwersytetu J agiellońskiego.

Barnes, C. (1997). Wizerunki niepetnosprawnych i media: badanie sposobów przedstawiania osób niepetnosprawnych $w$ środkach masowego przekazu, Lublin: PRINT 6.

Biblia Tysiąclecia Pismo Święte Starego i Nowego Testamentu (2000), Księga Kapłańska 21, 18-22.. Poznań: Wydawnictwo Pallotinum.

Biuro Pełnomocnika Rządu ds. Osób Niepełnosprawnych. (2011). Dane demograficzne. Narodowy Spis Powszechny Ludności i Mieszkań 2011. http:// www.niepelnosprawni.gov.pl/index.php?c=page\&id=78).

Biuro Pelnomocnika Rządu ds. Osób Niepełnosprawnych. (2015). Dane demograficzne. Europejskie Ankietowe Badanie Zdrowia (European Health Interview Survey - EHIS). http:// www.niepelnosprawni.gov. $\mathrm{pl} / \mathrm{p}, 78$,dane-demograficzne. 
Biuro Pelnomocnika Rządu ds. Osób Niepelnosprawnych. (2018), Badania Aktywności Ekonomicznej Ludności w IV kwartale 2018 r. http:// niepelnosprawni.gov.pl/p,81,bael.

Czyżewski, M., Franczak, K., Nowicka, M., Stachowiak, J . (2014). Dyskurs elit symbolicznych. Próba diagnozy. Warszawa: Wydawnictwo Akademickie SEDNO.

Damon, J . (2012). Wykluczenie. Warszawa: Oficyna Naukowa.

Esparcia, A.C., Smolak-Lozano E. (2012). Historyczny rozwój koncepcji teoretycznych na temat roli środków masowego przekazu w społeczeństwie. Lingua ac Communitas 22, 181-203.

Gibbs, G. (2011). Analizowanie danych jakościowych. Warszawa: Wydawnictwo Naukowe PWN.

Goffman, E. (2007). Piętno. Rozważania o zranionej tożsamości, Gdańsk: Gdańskie Wydawnictwa Psychologiczne.

Goffman, E. (2011). Relacje w przestrzeni publicznej. Mikrostudia porządku publicznego. Warszawa: Wydawnictwa Naukowe PWN.

Gustavsson, A., Zakrzewska-Manterys, E. (1997). Wprowadzenie w społeczny kontekst upośledzenia [w:] Upośledzenie w społecznym zwierciadle. (red.) Gustavsson A., Zakrzewska-Manterys E. Warszawa: Wydawnictwo „Żak”.

Hulek, A. (1991). Rola środków masowego przekazu w rehabilitacji inwalidów. [w:] Środki masowego przekazu a czlowiek niepetnosprawny. (red.) Hulek A. Warszawa: PolskieTowarzystwo Walki Kalectwem.

Janocha, W. (2009). Niepełnosprawność w kontekście egzystencjalnego i społecznego funkcjonowania rodziny. [w:] Rodzina wobec współczesnych wyzwań społeczno-kulturowych. (red.) Gorbaniuk J ., Parysiewicz B. Lublin: Wydawnictwo KUL.

Kalinowska-Sufinowicz, B. (2017). Teorie dyskryminacji ekonomicznej na rynku pracy a osoby z niepełnosprawnościami. Niepetnosprawność - zagadnienia, problemy, rozwiązania, 3, 12-31. 
Karaś, M. (2012). Niepelnosprawność, od spojrzenia medycznego do społecznego i Disability Studies. Przegląd Prawniczy, Ekonomiczny i Społeczny, 4, 20-33.

Kilian, M. (2007). Niepełnosprawni w społeczeństwie. Społeczne uwarunkowania niepelnosprawności w starszym wieku. Polityka Spoteczna, 11-12, 404-405.

Konecki, K. (2016). O socjologii jakościowej. Roczniki Nauk Społecznych, 8(4), 7-34.

Korniszowski, L. (2003). Dzieci z wadami wrodzonymi. Warszawa: Wydawnictwo Lekarskie PZWL.

Krause, A. (2009). Upośledzenie umystowe, niepetnosprawność umysłowa czy niepetnosprawność intelektualna? Kontynuacja przerwanej dyskusji. [w:] Pedagogika specjalna. Różne poszukiwaniawspólna misja. Pamięci Profesora Jana Pańczyka. (red.) BielskaŁach, M. Warszawa: Wydawnictwo APS.

Kuczyńska-Kwapisz, J . (2008). Rozwój tyflopedagogiki. [w:] Historyczne dyskursy nad pedagogika specjalna $w$ ujęciu pedagogicznym. (red.) Błeszyński, J J ., Baczała D., Binnebesel J . Łódź: Wydawnictwo Naukowe Wyższej Szkoły Edukacji Zdrowotnej.

Masłyk, T., Migaczewska, E., Stojkow, M., Żuchowska-Skiba, D. (2016). Niepetnosprawni $w$ świecie nowych technologii internetowych. [w:] Aktywni niepelnosprawni? Obywatelski i społeczny potencjat środowiska osób niepetnosprawnych. Kraków: Wydawnictwa AGH. Mercer, G., Barnes, C. (2008). Niepetnosprawność. Warszawa: Wydawnictwo Sic!

Minister Zdrowia. (2019). Rozporządzenie Ministra Zdrowia z dnia 21 marca 2019 r. w sprawie zlecenia na zaopatrzenie w wyroby medyczne oraz zlecenia naprawy uyrobu medycznego, Dz.U. 2019 poz. 582. http://isap.sejm.gov.pl/isap.nsf/ DocDetails.xsp?id=WDU20190000582 Molga T. (2018, 22 sierpnia). Byli skazani na bezrobocie i drwiny. Niepełnosprawni browarnicy sprzedali piwo za ponad milion. Wirtualna Polska, https:/ / wiadomosci.wp.pl/ byli-skazani-na-bezrobocie- 
i-drwiny-niepelnosprawni-browarnicy-sprzedali-piwo-za-ponadmilion-6287127696668289a.

Monitor Polski. (1997). Uchwała Sejmu Rzeczypospolitej Polskiej z dnia 1 sierpnia 1997r. - Karta Praw Osób Niepełnosprawnych, nr 50 poz. 475. Murawska-Najmiec, E. (2006). Informacja na temat istniejącego w Polsce systemu ochrony etyki dziennikarskiej. Analiza Biura KRRiT, 7. Nadolna, E., Piocha, S. (2009). Zatrudnienie osób niepelnosprawnych jako forma rehabilitacji zawodowej. W: Zeszyty Naukowe Wydziału Nauk Ekonomicznych Politechniki Koszalińskiej, 127-140.

Nadolna, E., Piocha, S. (2009). Zatrudnienie osób niepełnosprawnych jako forma rehabilitacji zawodowej. Zeszyty Naukowe Wydziału Nauk Ekonomicznych Politechniki Koszalińskiej, 13, 127-140.

Nelson, T.D. (2003). Psychologia uprzedzeń. Gdańsk: Gdańskie Wydawnictwa Psychologiczne.

Niedbalski, J ., Racław, M., Żuchowska-Skiba D. (2017). Wstęp. W kierunku nowego paradygmatu niepelnosprawności. Acta Universitatis Lodziensis. Folia Sociologica, 60, 5-12.

Ostrowska, A. (1997). Postawy społeczeństwa polskiego w stosunku do osób niepetnosprawnych. [w:] Upośledzenie w społecznym zwierciadle. (red.) Gustavsson A., Zakrzewska-Manterys E. Warszawa: Wydawnictwo „Żak”.

Podgórska-J achnik, D. (2013). Deprecjacja osób z niepetnosprawnością $w$ dyskursie publicznym. [w:] Człowiek z niepetnosprawnością. (red.) Gajdzica Z. Kraków: Impuls.

Polskie Badania Czytelnictwa. (2019). https:// www.pbc.pl/rynek-prasowy/.

Rada Etyki Mediów. (2003). Apel Rady Etyki Mediów. Niepelnosprawni.pl, http:// www.niepelnosprawni.pl/ledge/x/ 1979.

Sadowska, S. (2005). Ku edukacji zorientowanej na zmianę społecznego obrazu osób niepetnosprawnych. Toruń: Wydawnictwo Edukacyjne „AKAPIT”. 
Sękowski, A. (1994). Psychospoleczne determinanty postaw wobec inwalidów. Lublin: Wydawnictwo UMCS.

Shearer, A. (2002). Myśl pozytywnie! Jak przedstawiać ludzi z upośledzeniem umystowym. Warszawa: Polskie Stowarzyszenie na Rzecz Osób z Upośledzeniem Umysłowym.

Stownik Oxford Wordpower. (2002). Oxford: Oxford University Press. Stanisławski, P. (2003). Od ofiary do herosa. Integracja, 5.

Stratford, B. (1993). Zespót Downa, przesztość, teraźniejszość i przyszlość. Warszawa: Wydawnictwa Lekarskie PZWL.

Struck-Peregończyk, M. (2013). Wizerunek osób niepelnosprawnych w środkach masowego przekazu - zarys zjawiska. Kwartalnik Internetowy Komunikacja Spoteczna, 4(8), 22-31.

Struck-Peregończyk, M., Kurek-Ochmańska, O. (2018). Wizerunek osób niepelnosprawnych w polskiej prasie opiniotwórczej na przykładzie tygodnika „Polityka” wlatach 1997-2016. Przegląd Socjologii Jakościowej, XIV(3).

Szafraniec K., Szymborski P. (2015). Niepelnosprawni - przelamywanie stereotypówi barier integracji. Studia BAS, 2, 123-148.

Szczepaniak, K. (2012). Zastosowanie analizy treści w badaniach artykułów prasowych - refleksje metodologiczne. Acta Universitatis Lodziensis. Folia Sociologica, 42, 83-112.

Szymańska, M.J . (2018). Niepelnosprawność wzatrudnieniu wolnorynkowym. Aktualna sytuacja wnawiązaniu do przemian historycznych. Wyniki badań. Niepetnosprawność - zagadnienia, problemy, rozwiązania, 29(4), 36-50.

Tabernacka, M., Szadok-Bratuń, A. (2012). Public relations $w$ sferze publicznej. Wizerunek i komunikacja. Warszawa: Wolters Kluwer.

Union of the Physically Impaired Against Segregation. (1976). Fundamental Principles of Disability, London. https://disability-studies.leeds.ac.uk/ wp-content/ uploads/ sites/40/library/ UPIAS-fundamental-principles.pdf. 
Ustawa. (1991). Ustawa z dnia 9 maja 1991 r. o zatrudnianiu i rehabilitacji zawodowej osób niepełnosprawnych. Dz.U. 1991nr 46 poz. 201. http:/ / isap.sejm.gov.pl/isap.nsf/ DocDetails.xsp?id=WDU19910460201. Wiliński, M. (2010). Modele niepetnosprawności: indywidualny funkcjonalny - spoleczny. [w:] Diagnoza potrzeb i modele pomocy dla osób z ograniczona sprawnością. (red.) Brzezińska A., Kaczan R., Smoczyńska K. Warszawa: Wydawnictwo Naukowe Scholar.

World Health Organization. (2001). International Classification of Functioning, Disability and Health World. Geneva: WHO Library Cataloguing-in-Publication Data.

Young, S. (2014). Dzięki, ale nie jestem wasza inspiracją. TEDx Sydney, https:// www.ted.com/talks/stella_young_i_m_not_your inspiration_thank_you_very_much?language $=\mathrm{pl}$.

Zakrzewska-Manterys, E., (2003). Wizerunek medialny dziecka niepelnosprawnego. [w:] Dziecko we wspótczesnej kulturze medialnej. (red.) Łaciak B. Warszawa: Instytut Spraw Publicznych.

Zakrzewska-Manterys, E., Niedbalski, J . (2018). W drodze ku tożsamości - doświadczanie i (re)definiowanie niepełnosprawności. Przegląd Socjologii Jakościowej, 14(3), 7-11.

Zgromadzenie Ogólne Narodów Zjednoczonych. (2006). Konwencja ONZ o prawach osób niepełnosprawnych. Dz.U. z dnia 25 października 2012 r., poz. 1169. https:// www.rpo.gov.pl/pl/content/konwencja-onz-o-prawach-osob-niepelnosprawnych

Żuraw, H. (2016). Ewolucja podejścia do niepełnosprawności w kulturze zachodu - perspektywa antropologii. Pogranicze. Studia Spoteczne, 28, 27-47.

Materiał badawczy - wykaz artykułów

[1] Aborcja nie w moim interesie, „Wprost”, 29.01.18, $\mathrm{nr} 5$

[2] Agnieszka Dejna, „Newsweek”, 26.02.18, nr 9

[3] Aniol Stróż, „Newsweek”, 01.18, nr 4 
[4] Autyzm w kolorze, „Wprost”, 17.07.17, $\mathrm{nr} 38190$

[5] Bije, bo inaczej nie umie, „Newsweek”, 20.11.17, nr 48

[6] Ciało ze wspomaganiem, „Newsweek”, 31.07.17, $\mathrm{nr} 32$

[7] Ciekawość świata mam w DNA, „Wprost”, 13.11.17, nr 46

[8] CSR z korzyścią dla firmy i otoczenia, „Wprost”, 27.11.17, nr 48

[9] Do bram, na mury!, „Polityka”, 01.01.18, nr 1

[10] Do pracy rodacy!, „Polityka”, 01.01.18, nr 1

[11] Dziadek w wannie, „Newsweek”, 10.07.17, nr 29

[12] Dzieci do domu!, „Polityka”, 10.05.17, nr 19

[13] Genialny umyst $w$ bezwładnym ciele, „Newsweek”, 19.03.18, nr 13

[14] Gtowa, serce, ręce, zdrowie, „Polityka”, 26.07.17, nr 30

[15] Ile zarabiamy i czemu tak mało, „Newsweek”, 29.01.18, nr 6

[16] Jeden na jednego, „Polityka”, 17.01.18, nr 3

[17] Katarzyna Frank-Niemczycka, „Wprost”, 25.09.17, nr 39

[18] Kolej na pasażerów, „Wprost”, 07.01.18, nr 1

[19] Lenin późnego kapitalizmu, „Polityka”, 26.04.17, nr 17

[20] Mało rewolucyjnie o rewolucji, „Wprost”, 03.04.17, nr 14

[21] Miasta bez M, „Polityka”, 24.05.17, nr 21

[22] Monika pyta, „Polityka”, 12.04.17, nr 15

[23] Perty jak bomby, „Polityka”, 31.10.17, nr 44

[24] Pierwsza dania zabiera glos, „Wprost”, 27.11.17, nr 48

[25] Piętno cywilizacji, „Wprost”, 07.08.17, nr 38190

[26] Prosto w twarz, „Polityka”, 28.02.18, nr 9

[27] Przewodnik po 5oo+, „Wprost”, 07.08.17, nr 38190

[28] Przeżyj to sam, „Polityka”, 21.03.18 nr 12

[29] Ręka prosto z drukarki, „Newsweek”, 05.03.18, nr 11

[30] Robota dla Judyma, „Polityka”, 06.09.17, nr 36

[31] Równi i równiejsi, „Wprost”, 29.05.17, nr 38190

[32] Rzucanie kłód, „Polityka”, 22.11.17, nr 47,

[33] Seks jest dla ludzi, Wszystkich ludzi, „Wprost”, 30.10.17, nr 44

[34] Szkoła niepewności. MEN i niepetnosprawne dzieci, „Newsweek”, 05.06.17, nr 24

[35] Szukając idealnego ojca, „Newsweek”, 15.05.17, $\mathrm{nr} 20$

[36] Śmieszniej nad ta trumna, „Newsweek”, 19.03.18, nr 13

[37] Tanie, chętne, $w$ depresji, „Newsweek”, 18.09.17, nr 39, str.: 42.

[38] To jest wyścig, „Wprost”, 03.04.17, nr 14

[39] Tylko dla zdrowej tkanki narodu, „Wprost”, 6.02.18, nr 9

[40] Uciec przed Małyszem, „Newsweek”, 15.05.17, nr 20

[41] Uśmiechnięta twarz Lucasa, „Newsweek”, 12.02.18

[42] Wojna na obrazy, „Polityka”, 24.01.18, nr 4

[43] Z korzyścia dla pracowników i firm, „Polityka”, 24.05.17, nr 21

[44] Z mitości do życia, „Newsweek”, 28.08.17, nr 36

[45] Za życiem i... za wyborem, „Wprost”, 09.10.17, nr 41

[46] Zatrzaśnięci $w$ biedzie, „Polityka”, 21.02.18, nr 8 